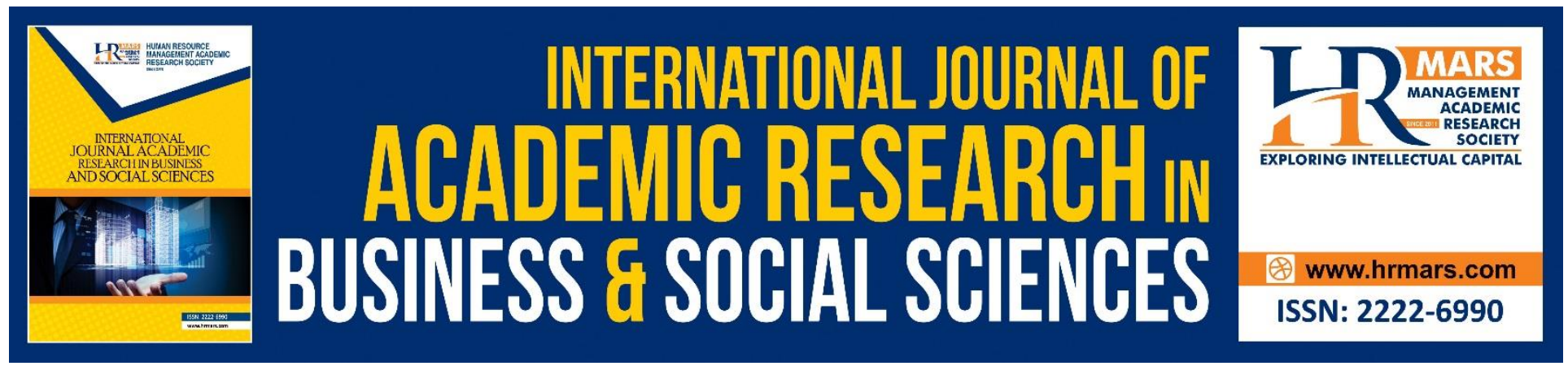

\title{
An Analysis of China-Africa Agricultural Cooperation and Prospects of Belt and Road Initiative: A Case of South Africa
}

Avuyile Xabadiya Zhiquan Hu

To Link this Article: http://dx.doi.org/10.6007/IJARBSS/v9-i2/5540

DOI: $\quad 10.6007 /$ IJARBSS/v9-i2/5540

Received: 14 Jan 2019, Revised: 26 Feb 2019, Accepted: 02 March 2019

Published Online: 03 March 2019

In-Text Citation: (Xabadiya \& Hu, 2019)

To Cite this Article: Xabadiya, A., \& Hu, Z. (2019). An Analysis of China-Africa Agricultural Cooperation and Prospects of Belt and Road Initiative: A Case of South Africa. International Journal of Academic Research in Business and Social Sciences, 9(2), 221-250.

Copyright: (C) 2019 The Author(s)

Published by Human Resource Management Academic Research Society (www.hrmars.com)

This article is published under the Creative Commons Attribution (CC BY 4.0) license. Anyone may reproduce, distribute, translate and create derivative works of this article (for both commercial and non-commercial purposes), subject to full attribution to the original publication and authors. The full terms of this license may be seen

at: http://creativecommons.org/licences/by/4.0/legalcode

Vol. 9, No. 2, 2019, Pg. 221 - 250

http://hrmars.com/index.php/pages/detail/IJARBSS

JOURNAL HOMEPAGE

Full Terms \& Conditions of access and use can be found at http://hrmars.com/index.php/pages/detail/publication-ethics 


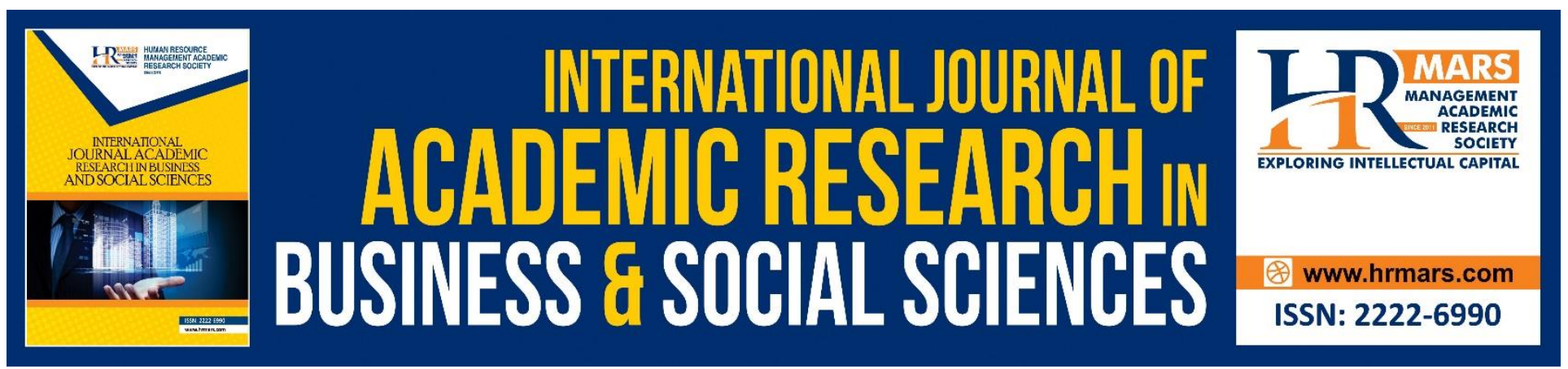

\title{
An Analysis of China-Africa Agricultural Cooperation and Prospects of Belt and Road Initiative: A Case of South Africa
}

\author{
Avuyile Xabadiya \\ Institute of Agricultural Economics and Development (IAED) \\ Chinese Academy of Agricultural Sciences (CAAS).12 Zhongguancun \\ Email: 20xabadiya@gmail.com \\ China Scholarship Council (CSC) and Department of Higher Education and Training (DHET), South \\ Africa funded this paper.
}

\section{Zhiquan $\mathrm{Hu}$}

Institute of Agricultural Economics and Development (IAED), Chinese Academy of Agricultural Sciences (CAAS).12 Zhongguancun, South Street, 10081.

Email: huzhiquan@caas.cn

\section{Abstract}

The aim of this paper was to assess the agricultural cooperation and agricultural trade that exists between China-Africa using South Africa as a case study. In addition, the research assessment provided the prospect of the Chinese Belt and Road Initiative into South African agriculture, taking into consideration the current existing agricultural cooperation between Africa and China. To assess the prospect, the research employed a descriptive analysis approach. Both secondary and primary data were employed. The research used a qualitative research method, for data selection of the primary data; a purposive sampling method was used. The secondary data was extracted from industry annual reports such as Agricultural Business Chamber, World Bank data. Open-ended interviews were conducted with 40 South African agricultural experts on their perspective on the prospect of Belt and Road and its future in the South African agricultural industry. The results indicate that South African agricultural experts are still pessimistic on working with China. They emphasized on China-South Africa agricultural cooperation that is formed on mutual respect despite the negative arguments on some of the Chinese engagements in African Agriculture. Finally, the areas of interests were agro-processing, export orientated produce, labour intensive produce and appropriate mechanization.

Keywords: Agricultural Cooperation, China, South Africa, Belt and Road, Trade 


\section{Introduction}

In recent times, China took a resolution to support African development through pledges and financial backing (Beijing review, 2017). China in 2006, released its African policy on economic cooperation (Sandry \& Edinger, 2009). This happened at the time when China's economic growth was shaping up and attracting many countries to learn about its policies, particularly the developing world (Cheung \& Qian, 2010). Additionally, China held its first Forum on China-Africa Cooperation (FOCAC), which was attended by almost all African leaders. The forum was the beginning of the foundation of China-Africa economic relations and cooperation.

Since 2006, China and Africa have been working closely with each other through FOCAC amongst others. Many scholars are continuously researching China-Africa relationships and the results are showing both positive and negative sentiments (Gumede, 2014). China is the biggest trade partner with African countries in particular in the mineral industry (Sandry \& Edinger, 2009) and food products. China's trade relationship with Africa continues to be amplified in political and economic forums (Beijing review, 2017 \& China Africa magazine, 2018).

China since joined the World Trade Organisation (WTO) in 2001, it has emerged as the global trade player and has become the "capital provider" in the developing world (Cheung \& Qian, 2010). At the time of global political and economic development such as Brexit and the election of President Donald Trump, who is implementing many protectionist policies against globalisation, China is becoming the global player in providing finance in the world, particularly in Africa (Beijing Review, 2017 \& China daily, 2017). According to the United Nations 2017 report (UNCTAD, 2017), China is the second largest foreign investor in developing countries.

China's trade relationship with Africa started taking a shape ever since China became the member of WTO and collaborations with South Africa, Nigeria, Kenya, Ethiopia and many other countries were seen as the major cooperation (Sandry \& Edinger, 2009). However, even though China-Africa cooperation is projected to increase and remain robust with a lot of political backing from African leaders, China has a trade surplus with Africa in many products (Sandry \& Edinger, 2009). This is a major concern for economists and policy makers including local producers in African countries. In addition, there is a call for major policy shifts to protect local manufacturing in Africa and the promotion of local economic growth. In South Africa, since the 2006 State of the Nation Address by former President Thabo Mbeki on Free Trade Agreement (FTA) with China, trade and cooperation between the two countries increased. During the presidency of former President Jacob Zuma, South Africa signed a Memorandum of Understanding (MoU) with China in 2015 FOCAC, held in Johannesburg (FOCAC, 2015). In 2016, China and South Africa signed an MoU for South Africa to export table grape to China and another MoU was signed for South Africa to provide China with beef meat. All these agreements are as results of cooperation agreements signed in 2015 between President Xi Jinping and President Jacob Zuma at FOCAC.

China is the largest trading partner with South Africa, and is the biggest trading partner compared to other African countries (Sandry \& Edinger, 2009). Since 2010, China has surpass traditional trading 
partners of South Africa, in 2016, the two countries had a bilateral trade of \$21.8 billion in 2016 (Msimang, 2018). Accordingly, since China took the spotlight of joining other Asian global players such as Japan, Malaysia, Singapore, Korea, all developing nations became interested in understanding how these developments would influence their own developments (Sandry \& Edinger, 2009).

China's achievements have been seen in many sectors, and these include: agriculture, industry, science and technology amongst others (Jonansein \& Amina, 2011). Accordingly, this led to Chinese emergence as a "manufacturing powerhouse" coupled with it being ranked the second largest economy in 2010 following the United State of America (Information office of the state council, 2010). Undoubtedly; Chinese emergence has raised many arguments regarding the implications to and the future of the African continent from across the world. Subsequently, some are optimistic that Chinese engagement presents "an opportunity for African's growth and development such as an increase in trade with China which might be of beneficial to African industries" (Jonansein 2011, Amina 2011,Van der Wath, 2004 and Draper, 2006).

On the contrary, others argued that this relationship might pose some serious threats to Africa's growth and development, considering that trade between China and Africa is in favour of China (Taylor, 2004 Jonansein \& Amina, 2011). Having discussed the various views on China-Africa economic, trade and diplomatic ties, the focus of this study is to assess the views of South African agricultural experts regarding China-South Africa agricultural cooperation in the future, to assess the current agricultural trade between South Africa and China and whether it is sustainable or beneficiary to both the countries. More specifically, this study analyzes activities in only Agriculture.

The results provide an insight of China's involvement in South African agriculture as it attempts to answer the following research questions;-

1. What is the nature of China-South Africa Agricultural trade?

2. What are the agricultural projects that are existing between China and Africa?

3. What are the views of South African agricultural experts on China South Africa cooperation in Agriculture for the future, considering different views on China's current engagement in African agriculture?

The paper will be arranged systematically as follows: section one covers introduction up to the China-Africa overview and the Belt and Road initiative, section two covers methodology, design and literature review, while section three will be the South African-China agricultural trade trends, with section four being the results and discussions, five conclusion and recommendation.

\section{Objectives}

\section{Main Objective:}

The main objective of the study is to evaluate South Africa-China agricultural cooperation at an aggregate level and assess prospects of the belt and road to South African Agriculture.

Accordingly, this main objective will be answered through the following specific objective;

- An assessment of China-South Africa agricultural trade trends (2001-2015).

- To assess the agricultural cooperation between South Africa and China

- Assess the prospects of Belt and Road Initiative between South Africa and China. 


\section{Problem Statement}

South Africa and China relations in the last 20 years have been increasing drastically with a lot of developments and strategic partnerships (Msimang, 2018). These relations have a strong political backing, which according to former President Jacob Zuma presents an opportunity for South Africa and China. All the former Presidents of South Africa have seen China as an important ally since the time of the struggle and they see nothing wrong to continue to cooperate economically with China even during the time of independence. Against this understanding, the years: 2000 partnership, 2004 strategic partnership and 2010 strategic partnerships, which saw China-South Africa economic trade reaching \$21.8 billion high in 2016 is a testimony of the economic activities that are happening between the two countries (Msimang, 2018).

However, these trade surpluses have attracted many scholars and policy makers in the importing countries about the impacts of China imports (Gumede, 2014).In addition, studies regarding trade imbalances have been carried. However, there is no study that assesses the agricultural cooperation between South Africa and China and the plan how these countries could assist each other in addressing the negative balance of payment, except the 2015 agreements signed at the Forum of China-Africa Cooperation. This study then attempt to assess how much agricultural cooperation exists in Africa and between South Africa and China and what improvements that could be done to fast track this cooperation to boost South African Agriculture.

\section{Justification of the Study}

Feeding a 9 billion, estimated world population by 2050 will require more cooperation from the world economies. Strengthening cooperation and diffusion of scientific proven knowledge and methods will be needed to decrease the hunger that is faced by the developing economies and those that are still poor. Accordingly, more agricultural information sharing needs to take place in fighting poverty alleviation between countries. The world draws inspiration from the works of Mexico through the green revolution that was introduced during the 1950s, which spread across to Asia during the 1960s and continued through to reaching China in the 1990s through research spillovers and diffusion of knowledge. It is therefore important for Africa to hear the call by China through its Belt and Road Initiative (B\&R) for the continent to benefit from the technological advances of China.

With no doubt, China's reforms and technological advances are worth noting and assessed as they represents an opportunity for other developing nation to learn and adopt where necessary. Notwithstanding the current agricultural cooperation between china and Africa, but South Africa need to strengthen its agricultural cooperation with China to overcome some of the challenges it faces because China presents an opportunity for South Africa to learn.

China is currently feeding almost $21 \%$ of the world's population with less than $9 \%$ of the world's arable land (Tang et al, 2011). A country such as South Africa with a lot of arable unused land (Wandile, 2018) can learn a lot from a country that is able to feed more with less of its resources using technological innovations that are able to produce even during different climatic conditions that are pressing the world. China through its continuous opening up policy introduced what is called 
"the Belt and Road initiative" to try and working with the world (Xi Jinping, 2014). The belt and road initiative presents an opportunity for South Africa to benefit more in particular during this period where the South African economy is expected to grow at an average of $1.2 \%$ in the next 10 years (Stats SA, 2017).

In order to assess what opportunities the belt and road can provide in the future between the two countries, it is important to first understand the global economic environment these countries are operating under first, understand the current cooperation, their benefits and challenges as well as failures if there are any failures. Evaluating the cooperation will give light to the direction the future cooperation could take and assist policy makers from both countries to be able to shape future policy directions, taking reference from the evaluation of this document.

\section{Limitation of the study}

The scope of the study is limited to cooperation between South Africa and China. The research will be limited to descriptive data analysis of the existing trends and the views of the agricultural experts from South Africa, on China-South Africa agricultural collaborations in the future. The paper will not look on China-South Africa economic activities other than agricultural related activities. In addition, it will only focus on South African agricultural activities with China, trade and potential future cooperation.

\section{Literature Review}

The BRICS countries have been driving a new "development cooperation" within itself and in the African continent (Scoones et al., 2016). Scoones et al (2016), argues that there is new shift by developing countries to work with African countries on cooperation in many respects including agricultural development (Gu \& Carty, 2014; White, 2013). There are criticisms for the emergence of these developing countries particularly when it comes to their engagements with African countries (Bong \& Garcia 2018; Lumumba-Kasango, 2011). However, there are also arguments that some of these critics are too simplistic and rhetoric and do not necessarily outline the complexities of these engagements by China, Brazil in Africa and their developmental roles they continue to play (Alden,2007;Brautigam \& Xiaoyang,2009;Carmody,2013; Taylor 2009;Taylor 2014). Furthermore, they argue that, there is subtle meaning in those South-South engagements when looked thorough.

Accordingly, several studies have been carried on the China and Brazil engagements in African agriculture through the framework of new "development cooperation" and its "features" (Scoones et al., 2016; Kim, 2015;Li \&Carey,2014). China, through Chinese Ministry of Commerce (MOFCOM), has established what is called "Business-run Chinese Agricultural Technology Demonstration Centres" (ATDCS) across the African continent, "as part of a the flagship agricultural development cooperation program"(Tugendhat \&Alemu 2016). Accordingly, these centers vary according to the purpose and the region they are operation under and are operated mostly by different companies from China, some from state-owned national, provincial level, local, individual enterprises among others (Scoones et al., 2016). 
According to Scoones .,(2016), "Building networks, soliciting political and commercial alliances, and training technicians and bureaucrats are all part and parcel of creating new platforms for capital expansion. While overt "land grabs" have not by-and-large been part of this, the expansion of business interests in mining, construction, and infrastructure development has very often preceded investments in agribusiness" (Weng et al 2013). This then implies that Chinese engagements in Africa are not necessarily about taking land for its only selfish interests as per other narratives written out there about the skepticisms of the emergence of the "New Powers".

Recent studies of China-Africa agricultural cooperation used case studies to analyze their findings (Amanor \& Chichava 2016). Accordingly, their results give a more complex and thorough balanced understanding of different cooperation in agriculture by Countries such as Brazil in Mozambique, China, in Zimbambwe and Ghana for example (Zhang et al 2015;Amanor \& Chichava 2016)

Brazil within the South-South engagement with Africa has been very prominent and many projects from Brazil such as ProSAVANA have been researched and analyzed (Scoones, 2016). He argues, "South-South Cooperation needs to be analyzed within a framework of changing patterns of aid and investment, and changing capitalist relations. Increasingly, northern development cooperation is driven by private sector interests and alignments between the private and public sectors, and policy is influenced by commitments to capital accumulation and growth". There has been a growing and evidence of the presence of agricultural technologies and rural development strategies from countries such as Brazil, China and India in Africa.

Literature suggest that FDI in agriculture differs depending on the nature of the investor country, whether its developed or developing (Zhang, Y 2010; Amendolagine, 2013). According to Santangelo (2018) , FDIs on land by developed countries have proven to be contributing to the food security of the host countries as they contribute by increasing the areas of production. On the other hand, FDIs on land by developing countries "hamper" food securities of host countries (Zhang, Y 2010; Amendolagine, 2013). Additionally, these evidence-based findings suggest that all the host countries would skeptical of the nature of the investor country and its contributions towards the local contributions. Inevitable so South Africa is one of the countries that have laws that are very open and critical of investments that do not seeks to benefit the local people.

Table 1: Studies on South-South agricultural cooperation in Africa. 
International Journal of Academic Research in Business and Social Sciences Vol. 9, No. 2, Feb, 2019, E-ISSN: 222 2-6990 @ 2019 HRMARS

\begin{tabular}{|c|c|c|c|}
\hline Authors, Year & Study topic & Methods of analysis & Findings \\
\hline Clever Mapaure, 2014, & $\begin{array}{l}\text { Chinese Investments in } \\
\text { Zimbabwe \&Namibia, } \\
\text { a comparative legal analysis }\end{array}$ & $\begin{array}{l}\text { a qualitative, interpretivist } \\
\text { approach }\end{array}$ & $\begin{array}{l}\text { African countries also need } \\
\text { to be transparent about the } \\
\text { deals that they sign with } \\
\text { China. Lack of transparency } \\
\text { raises unnecessary suspicions } \\
\text { and unfounded conclusions } \\
\text { about Chinese investments in } \\
\text { Africa }\end{array}$ \\
\hline $\begin{array}{l}\text { Kojo S.Amanor \& Sérgio } \\
\text { Chichava, 2016, }\end{array}$ & $\begin{array}{l}\text { South-South Cooperation, } \\
\text { Agribusiness, and African } \\
\text { Agricultural Development: } \\
\text { Brazil and China in Ghana } \\
\text { and Mozambique }\end{array}$ & Case Studies and Interviews & $\begin{array}{l}\text { There are complex } \\
\text { sentiments when it relates to } \\
\text { these developments. both } \\
\text { positive and negative } \\
\text { sentiments }\end{array}$ \\
\hline $\begin{array}{l}\text { Henry Tugendhat and Dawit } \\
\text { Alewu, 2016, }\end{array}$ & $\begin{array}{l}\text { Chinese Agricultural Training } \\
\text { Courses for African Officials: } \\
\text { Between Power\& } \\
\text { Partnerships }\end{array}$ & $\begin{array}{l}\text { Interviews and secondary } \\
\text { data using descriptive } \\
\text { analysis }\end{array}$ & $\begin{array}{l}\text { More than } 10000 \text { African } \\
\text { officials are trained by } \\
\text { Chinese Annually }\end{array}$ \\
\hline $\begin{array}{l}\text { Alex Shankland and Euclides } \\
\text { Goncalves, 2016, }\end{array}$ & $\begin{array}{l}\text { Imagining Agricultural } \\
\text { Development in South-South } \\
\text { Cooperation: The } \\
\text { Contestation \& } \\
\text { Transformation of } \\
\text { ProSAVANA }\end{array}$ & $\begin{array}{l}\text { Imaginaries, GIS maps. } \\
\text { Qualitative descriptive } \\
\text { research analysis }\end{array}$ & $\begin{array}{l}\text { There is a wide context of } \\
\text { state-society debates around } \\
\text { South-South cooperation in } \\
\text { Mozambique-Brazil. }\end{array}$ \\
\hline Scoones et al.,2016 & $\begin{array}{l}\text { New politics of Development } \\
\text { Cooperation? Chinese and } \\
\text { Brazilian Engagements in } \\
\text { African Agriculture }\end{array}$ & $\begin{array}{l}\text { Primary Interviews and } \\
\text { secondary data using } \\
\text { descriptive analysis }\end{array}$ & $\begin{array}{l}\text { There is a huge role played } \\
\text { by state-business relationship } \\
\text { in shaping development in } \\
\text { African agriculture }\end{array}$ \\
\hline $\begin{array}{l}\text { Clàudia Dias \&Màrio } \\
\text { Franco,2018 }\end{array}$ & $\begin{array}{l}\text { Cooperation in Transition or } \\
\text { Tradition in Cooperation? } \\
\text { Networks of Agricultural } \\
\text { Entrepreneurs }\end{array}$ & $\begin{array}{l}\text { Qualitative approach and a } \\
\text { case study method }\end{array}$ & $\begin{array}{l}\text { There is a huge benefits } \\
\text { through inter-organizational } \\
\text { cooperation }\end{array}$ \\
\hline
\end{tabular}

Source: Compiled by author from the above studies

There are no studies between South Africa-China agricultural cooperation and engagements in agriculture except on trade (Sandrey \& Edinger 2009), news articles (Grimm et al, 2014) and recent agreements signed by governments for future agricultural working relations (FOCAC, 2018). 
However, there are studies on China-South African strong economic relations and its future prospects (Lehlogonolo, 2016).

Lehlogohono(2016), when assessing China-South Africa comprehensive relationship, he aligned his study to a "Neo-liberal Institutionalism" theory. In addition, he argued, "Neo-liberal institutionalism argues that states are rational international actors and thus, it is in their rational state behavior to enter into cooperation with other states, to maximize their mutual interests and absolute gains, in a harsh and unpredictable international system. China and South Africa benefit from mutual interests and maximum absolute gains in their cooperative partnership, through rapid and extensive bilateral trade relations"

Table 2: Some Notable collaborative business between South Africa-China entities.

\begin{tabular}{lll}
\hline Chinese Companies involved with SA & Nature of the partnership & In current status \\
Companies & & Good \\
\hline Huawei(China) \& MTN(RSA) & Joint Venture(JV) & Good \\
Zinjin Mining Group(China),Ridge & JV & \\
Platinum mining Company, Sino Steel\& & & \\
Samancor(rSA) & & \\
& Nature of the partnership & In current status \\
SACompanies involved with Chinese & & Good \\
Companies & JV & Good \\
Naspers(RSA) \& Tencent(China) & JV & \\
SABMiller(RSA)\& China Resources & & Good \\
$\begin{array}{l}\text { Enterprice(China) } \\
\text { Standard Bank(RSA)\& ICNC }\end{array}$ & JV & \\
\hline
\end{tabular}

Source: Compiled by author from lehlogonolo's study

Lehlogonolo (2016), note that China-South Africa cooperation in business has special characteristics such as Mergers and Acquisitions. He argues that when China invests in South Africa, It does not open its new factory but partners with the local entity that is operating within the areas of interest of the investor enterprise. Unsurprisingly, when South Africa also invests in China, it buys stocks into an existing entity.

\section{Methodology and Research Design \\ Methodology}

According to Rajasekar et al (2013), "methodology is a systematic way to solve a problem. It is a science of studying how research is to be carried out. Essentially, the procedures by which researchers go about their work of describing, explaining and predicting phenomena are called research methodology. In this research, the data will be collected from well-known organizations 
such as World Development Indicators, DAFF, NAMAC for South African agriculture data. Department of Trade and Industry will be used for trading trends in South Africa.

\section{Research Design}

Bless et al(2013), define research design as a detailed outline for the testing of a hypothesis [or answering of research questions], spelled out in clear and definite terms and is a specification of the most appropriate operations which need to be performed in order to test a specific hypothesis [or answer a research question] under given conditions.

This research is a qualitative research design study (Pope .C \& Mays .N 2000,Nkwi P et al 2001, Bless et al 2013). In-depth descriptions of the agricultural cooperation between South Africa and China will be assessed. The existing agricultural cooperation between the two countries and future prospects will also be assessed. Drawing from the unit of analysis, which is in this case International agriculture cooperation, and the main actors, are South Africa and China in cooperation.

\section{Qualitative Research Design}

Bless et al (2013:) suggests that a research design implies a sketch or a blueprint outlining the process through primary data is collected, evaluated, measured, analysed and interpreted, findings can be generalised from a relatively sample. According to Saunders et al (2012), qualitative research is associated with interpretive philosophy because it needs to make sense to the subjective and socially constructed meaning expressed about the phenomenon being studied(Schesul J \& LeComote $M$,1999). Qualitative research is done by collecting data and analysing it(Pelto P \& Pelto $G, 1997)$. This design is very relevant to the study because this study is based on getting facts from individuals. In this case to achieve objective three, agricultural experts from South Africa were interviewed using an open-ended questions.

\section{Descriptive Study}

Using a descriptive study is to gain an accurate profile of events persons or situation. It is necessary to have a clear picture of the phenomenon through which you want to collect data. A descriptive study focuses on describing a certain situation and then collected data will be analysed to come with conclusion (Sounders et al, 2012). Therefore, this study to achieve objective 3, it will have a one on one interview sessions with agricultural experts in South Africa.

\section{Sampling Method}

The population target of the study is the agricultural experts in South Africa, University professors, government officials and directors of agricultural enterprises. a specific sample was selected from each sphere of leadership. In addition, these experts will be able to give valid information for the study. The study used the purposive sampling method. Accordingly, this means that, open-ended questions were formed and asked from 40 agricultural experts from South Africa about prospects of Belt and Road Initiative in the agricultural sector.

\section{Table 3: Data collection and target population for the prospect of B\&R into South Africa}




\begin{tabular}{lllll}
\hline $\begin{array}{l}\text { Population } \\
\text { Number(40) }\end{array}$ & $\begin{array}{l}\text { University } \\
\text { Professors }\end{array}$ & $\begin{array}{l}\text { Directors } \\
\text { of } \\
\text { Companies }\end{array}$ & $\begin{array}{l}\text { Government } \\
\text { officials(including } \\
\text { local government } \\
\text { officials) }\end{array}$ & $\begin{array}{l}\text { Data } \\
\text { Collection } \\
\text { Methods }\end{array}$ \\
\hline Sampling Size & 15 & 10 & 15 & $\begin{array}{l}\text { One-one } \\
\text { Interviews }\end{array}$ \\
\hline
\end{tabular}

SOURCE: AUTHURS COMPILATION

\section{The Overview of China-South Africa Agricultural Trade}

Global trade shape has been changing for some time in the past decades. Accordingly, a feature of many new players into the market has been caused by United States imports. Asian country's emergence as full participants into the global trade meant that global tariffs behaviour would shift in favour of globalization (Sandrey \& Edinger, 2009). China followed other Asian international players such as Malaysia, Japan, and Singapore, which meant that it also would pose a threat as a competitor to many exporting nations (Nguyen, 2016).

Certainly, China's economic evolution has sparked a lot of attention from many economic role players across the globe. In that regard, China's economic growth has been followed by many countries including South Africa, which on its own underwent a trade liberalization. In addition, China's growth presented an opportunity for South African raw products to facilitate its manufacturing industry. On the other side, China posed as a threat to Asian markets but many studies have observed that China exports do not necessarily pose a threat to African market (Nguyen, 2016). In that regard, this section seeks to understand agricultural trade trends between South Africa and China.

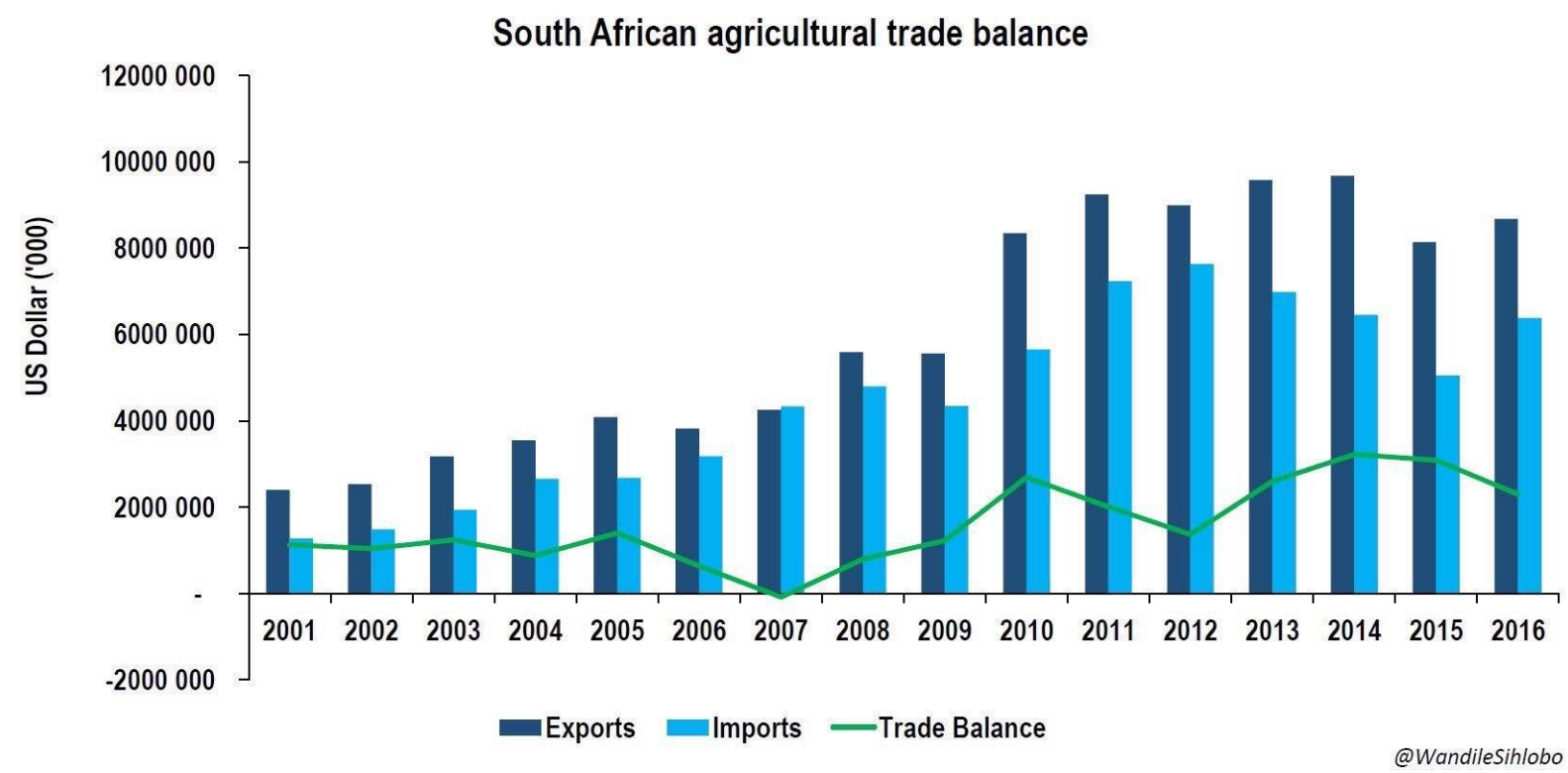


Figure 1: Value of South African agricultural trade balance, 2001-2016(US dollar,000), Source:Wandile Sihlobo,Agbiz

Exports of agriculture in South Africa have been positive for a long time as indicated in figure 1 above. The trade balance has been positive and an increase in the trade balance can be observed in the period under review.

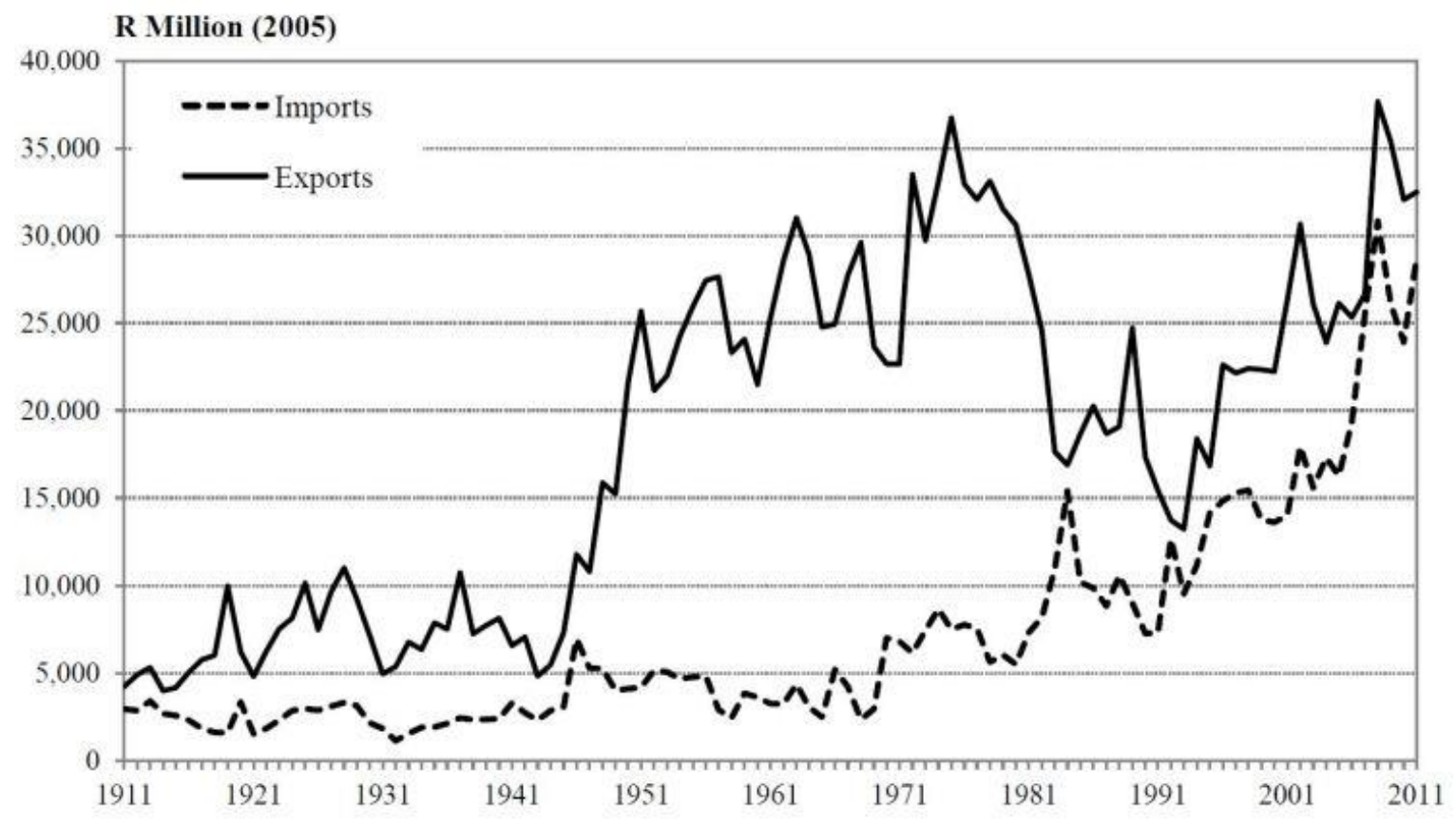

Figure 2: The South African agricultural exports and imports,1911-2011.Million rands(2005 base year) ,Source:Liebenberg, Wandile Sihlobo,Agbiz.

As indicated in figure 2, agricultural exports in South Africa maintains a positive trade balance since 1911 untill 2011. The diagram is a confirmation of the well reported triving agricultural exports of South Africa into the world. 


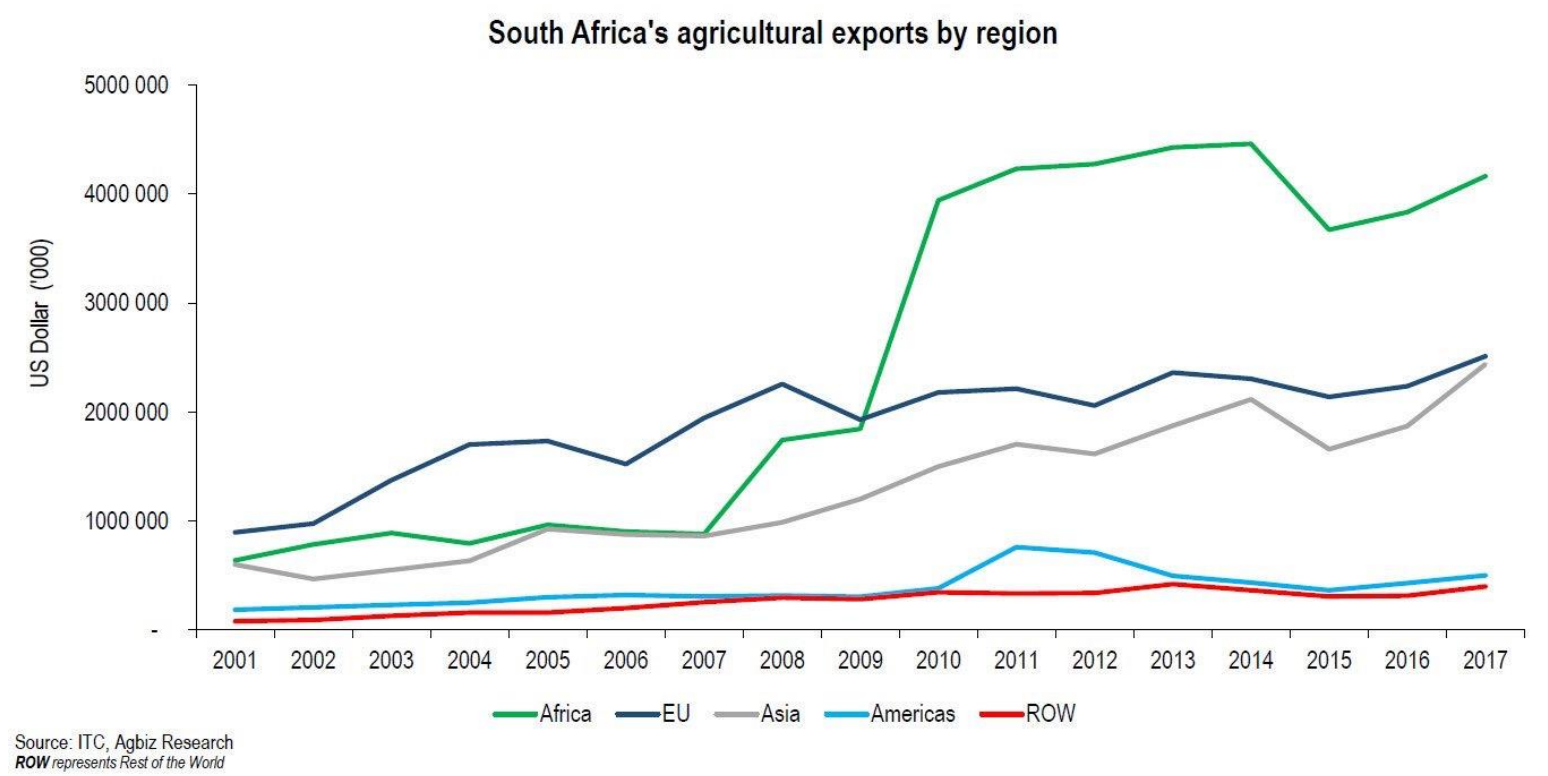

Figure 3: The South Africa's agricultural exports by regions,2001-2017(US Dollars,000)

European Union (EU) for a long time has been a largest region to receive South African agricultural exports as indicated from 2001 up until 2009. In 2009, Africa surpassed EU as the largest trading partner with South Africa, followed by Asia. According to Le Pere \& Draper (2005), ever since China joined the World trade Organization in 2001, it played within the rule and traded with many countries such as South Africa. Trade relations between the two countries have been increasing (Le Pere \&Draper, 2005). China has strengthened its trade relationship with Africa through bilateral and multilateral forums (Sandrey \& Edinger, 2009).

South Africa and China have already had a protocol of Phytosanitary requirements for the export of maize, which was signed in Beijing on the 4th December 2014. The protocol specifies the specific pests of concern to China, which warrant quarantine. The Agricultural Business Chamber (Agbiz) indicated that South Africa could potentially increase its sorghum exports to other key sorghum consuming countries, including China. "The export of grains to china is expected to increase in the next growing seasons, while these prospects might be deflated by the impact of the drought, a return to normal weather conditions will see South Africa re-building its stocks. With policy uncertainty surrounding national bio-fuel projects on the one hand, land reform and a relatively saturated regional market on the other, there is likely to be a renewal of interest in the Asian markets for exportable surpluses “(Kapuya, 2016).

The Department of Agriculture, Forestry and Fisheries (DAFF, 2016) pointed out two important aspects of the Chinese market that are worth noting. Firstly, that China constitutes the bulk estimated at $70 \%$ of the Asia Pacific's fruit and vegetable market. China is the 7th largest importer of edible fruits in the world (ITC, 2015). China imports about 35, 527 tons apples and pears (apples accounting for 28,000 tons of this) annually. Secondly, according to DAFF (2016), China has a decent regulatory environment and a good grocery penetration, including a well-developed retailing sector that 
presents scope for expansion. They also note that China's food safety, labelling or MRL regulations do not present any problems for South African exports of fresh produce.

South Africa is among the most competitive exporters of fresh produce in the world. The country is a leading exporter of oranges globally, while being a leading apple exporter in the African continent "(Kapuya, 2016; Wandile, 2018). South African apples recently got market access into China, while mangoes are still awaiting approval for access. However, South Africa's competitiveness in the Chinese market is affected by high tariffs. For instance, South Africa faces $11 \%$ duty for oranges; $10 \%$ for apples; $13 \%$ table grapes; and $35 \%$ for mangoes in the Chinese market. The fresh produce includes; fresh grapes, guavas, mangoes, oranges and apples. Undoubtedly, China's agricultural imports have been dramatically going up over the last decade and South Africa has become one of the crucial suppliers of these imports such as oranges, wool amongst others.

\section{South Africa-China Agricultural Trade trends}

Trade between South Africa and China has grown tremendously in the past years, with overall bilateral trade growing from US\$1.5 billion in 2001 to $\$ 23$ billion in 2015(Kapuya, 2016). The value of all agricultural commodity trade grew from US\$67 million to US\$655 million during the period under review. This includes inputs trade. Traditionally, South Africa has had a net deficit in terms of the agricultural trade balance. South Africa has imported more agricultural products from China than it exports ever since China assumed a position into the WTO. However, since 2014, South Africa saw a positive trade balance for agriculture with China as already mentioned above.

Bilateral trade in agricultural products has been relatively small in terms of share of total trade, ranging between $2 \%$ and $6 \%$ of total trade over the past decade. The share of total trade has, however, averaged 3\% between 2012 and 2015. The bilateral trade between South Africa has dropped by $25 \%$ in value between 2012 and 2015. This overall decline has been attributed, to a large degree, by the fall in South Africa's agricultural imports from China - which fell by $50 \%$ from US\$576 million in 2012 to US\$289 million in 2015. The drop in South Africa's agricultural imports from China was mainly attributed to the decline in apples $(-30 \%)$, kidney beans $(-70 \%)$, glucose and glucose syrup $(-17 \%)$, animal feed preparations $(-33 \%)$, sugar confectionary $(-12 \%)$, and plain weave cotton fabrics $(-17 \%)$, among others. South Africa's agricultural exports have increased over the period under review by 24\% - from US\$295 million in 2012 to US\$366 million in 2015.

Macadamia nuts, grapefruit, peaches, oranges, fine animal hair and grape wines, among others, have driven the increased agricultural export to china. Even though South Africa's growth in agricultural exports to the world in 2015 fell by $10 \%$ (from US\$10 billion to US\$9.1 billion), the value of South Africa's agricultural exports to China grew by $5 \%$ compared to 2014. However, despite South Africa is growth in agricultural exports in the Chinese market, China's agricultural imports slowed by $4 \%$ over the period under review (NAMC, 2016).

Table 4: South Africa's Agricultural Exports to China, US\$ 000(2011-2015) 


\begin{tabular}{|c|c|c|c|c|c|c|c|}
\hline Rank & $\begin{array}{l}\text { Product } \\
\text { Code }\end{array}$ & Product level & 2011 & 2012 & 2013 & 2014 & 2015 \\
\hline 1 & 510111 & $\begin{array}{l}\text { Greasy Shorn } \\
\text { wool }\end{array}$ & 112,174 & 176,312 & 194,838 & 186,457 & 174,692 \\
\hline 2 & 220421 & $\begin{array}{l}\text { Grape wines in } \\
\text { containers }<2 \text { litres }\end{array}$ & 20,000 & 24,947 & 20,245 & 18,132 & 34,619 \\
\hline 3 & 080510 & Oranges & 8,541 & 11,168 & 16,670 & 23,488 & 27,806 \\
\hline 4 & 510539 & $\begin{array}{l}\text { Fine animal hair, } \\
\text { carded or combed }\end{array}$ & 11,861 & 11,523 & 14,401 & 19,357 & 20,933 \\
\hline 5 & 230120 & $\begin{array}{l}\text { Flour meal unfit } \\
\text { human } \\
\text { consumption }\end{array}$ & 18,222 & 24,389 & 2,033 & 23,017 & 17,551 \\
\hline 6 & 200870 & Peaches & 2,074 & 3,038 & 4,854 & 11,219 & 14,864 \\
\hline 7 & 080561 & $\begin{array}{l}\text { Macadamia nuts, } \\
\text { in shell }\end{array}$ & 0 & 207 & 280 & 0 & 12,887 \\
\hline 8 & 080540 & Grapefruit & 816 & 839 & 5,831 & 7,678 & 11,384 \\
\hline 9 & 080540 & Edible nuts & 0 & 0 & 348 & 1,699 & 9,081 \\
\hline \multirow[t]{3}{*}{10} & 030621 & $\begin{array}{l}\text { Rock lobster \& } \\
\text { other } \\
\text { crawfish }\end{array}$ & 18,951 & 13,610 & 15,914 & 14,587 & 5,100 \\
\hline & & $\begin{array}{l}\text { Total of top } 10 \\
\text { agricultural } \\
\text { exports }\end{array}$ & 192,639 & 266,033 & 275,414 & 305,634 & 328,897 \\
\hline & & $\begin{array}{l}\text { Total overall } \\
\text { agricultural } \\
\text { exports }\end{array}$ & 234,800 & 295,310 & 307,534 & 349,436 & 366,215 \\
\hline
\end{tabular}

Source: Agricultural business chamber (Agbiz)

South Africa's top 10 agricultural exports constitute an average of $86 \%$ of the country's total agricultural exports to China between 2011 and 2015. This means that South Africa's agricultural exports are very concentrated among a few products. Of the top 10 products, greasy shorn wool constituted almost half of the country's total agricultural exports to China in 2015, with a value of US\$175 million. Over the past 7 years, greasy shorn wool have averaged $54 \%$ of South Africa's agricultural exports to China. As shown in Table 4, Grape wine exports in containers of less than or equal to 2 litres accounted for $9 \%$ of South Africa's total agricultural exports to China. Oranges accounted for $8 \%$, followed by fine animal hair (6\%), flour, meal and pellets of fish not fit for human consumption (5\%), peaches (4\%), macadamia nuts $(4 \%)$ grapefruit $(3 \%)$, edible nuts $(2 \%)$, rock lobsters, and crawfish (1\%).

South African fruit exporters have noted that when considering exports to China, it is important to take into account both direct and indirect exports, more specifically, exports through Hong Kong. According to the DAFF (2016), South Africa's direct shipments of fruit to China have increased from 
5,000 to 45,000 tons on the one hand, while shipments through Hong Kong increased from 60,000 to 105,000 tons over the same period, on the other.

Table 5: South Africa's Agricultural Exports to China including exports shipments via Hong Kong, US\$ 000(2011-2018)

\begin{tabular}{llllllll}
\hline Rank & $\begin{array}{l}\text { Product } \\
\text { Code }\end{array}$ & Product level & $\mathbf{2 0 1 1}$ & $\mathbf{2 0 1 2}$ & $\mathbf{2 0 1 3}$ & $\mathbf{2 0 1 4}$ & $\mathbf{2 0 1 5}$ \\
\hline $\mathbf{1}$ & 510111 & $\begin{array}{l}\text { Greasy Shorn } \\
\text { wool }\end{array}$ & 147,177 & 176,457 & 194,838 & 186,457 & 174,692 \\
$\mathbf{2}$ & 080561 & $\begin{array}{l}\text { Macadamia nuts, } \\
\text { in shell }\end{array}$ & & 19,073 & 45,554 & 67,345 & 74,341 \\
& & & & & & \\
$\mathbf{3}$ & 080510 & Oranges & 42,890 & 35,902 & 30,123 & 45,430 & 57,419 \\
$\mathbf{4}$ & 220421 & Grape wines in & 23,397 & 28,849 & 23,440 & 21,043 & 37842 \\
& & containers<2litres & & & & & \\
$\mathbf{5}$ & 080540 & Edible nuts & 13,739 & 36,324 & 24,456 & 33,491 & 37,536 \\
$\mathbf{6}$ & 080610 & Fresh Grapes & 31,710 & 39,634 & 30,876 & 29,174 & 28,023 \\
$\mathbf{7}$ & 200870 & Peaches & 15,163 & 17,109 & 18,225 & 22,502 & 25,065 \\
$\mathbf{8}$ & 080550 & Lemons & 8,517 & 8,967 & 8,781 & 42,393 & 24,137 \\
$\mathbf{9}$ & 510539 & Fine Animal hair & 11,861 & 11,523 & 14,401 & 19,357 & 20,933 \\
$\mathbf{1 0}$ & 030789 & Other abalone & 0 & 16,188 & 9,468 & 18,865 & 19,943 \\
& & Total of top 10 & 294,454 & 390,026 & 400,162 & 486,157 & 499,911 \\
& & agricultural & & & & & \\
& exports & & & & & \\
& Total overall & 490,556 & 537,532 & 523,169 & 653,466 & 634,290 \\
& agricultural & & & & & \\
\hline
\end{tabular}

Source: Agricultural business chamber (Agbiz)

This means that indirect shipments of fruit (via Hong Kong) account for as much as $70 \%$ of exports to mainland China. Table 5 shows South Africa's top 10 agricultural exports to China, after including Hong Kong. A comparison of Table 4 and 5 shows a number of notable differences in the ranking of products and commodities. Greasy shorn wool maintains its pole position as South Africa's leading agricultural export product into China, and oranges maintain third position, with the latter doubling in value. However, macadamia nuts rise from being the 7th largest agricultural export to 2nd, increasing from US\$13 million to US\$74 million in 2015. Fresh grapes and lemons get into the list of South Africa's top 10 agricultural exports to China, reflecting the importance of Hong Kong as a key market route for the two products.

\section{China's notable agricultural activities in Africa}

Agro-processing in Africa, particularly west and east Africa is championed by African Development Bank. About 100 projects valued at US 2.97 billion (African Development Bank) through its agriculture 
policy strategy (2015-2019). The African Union's (AU) Comprehensive African Agricultural Development Programme (CAADP) drives the industrialization of African Agriculture.

\section{Table 6: Number of Chinese Agricultural Firms operation in East and West Africa}

\begin{tabular}{llll}
\hline Region & $\begin{array}{l}\text { Number } \\
\text { countries }\end{array}$ & $\begin{array}{l}\text { of } \\
\text { Number } \\
\text { Chinese } \\
\text { firms }\end{array}$ & $\begin{array}{r}\text { of } \\
\text { agro- }\end{array}$ \\
\hline East Africa & 17 & 73 \\
West Africa & 16 & 57 \\
Central & 9 & 34 \\
North & 7 & 17 \\
Southern & 5 & 4 \\
Share of East \& & 33 & 130 \\
West & & & \\
Total & $\mathbf{5 4}$ & $\mathbf{1 8 5}$ \\
\hline
\end{tabular}

Source: Authors compilation from SAllA

Chinese firms (185 firms) operate in almost all African countries (54), as per the table 6 above. All these firms are agricultural firms. China State Farms Agribusiness Corporation (CSFAC) is one of the major players in identifying and distributing Chinese Agricultural investments in Africa (SAllA, 2015). China Exim Bank, CDB, Industrial and Commercial Bank of China among other are at the centre of providing soft loans and funding industrialized agriculture with African States (SAllA, 2011). In 2006, a State farm of Chinas Shanxi province announced its investment in 5000 hector Cassava and Rice plantation in Cameroon funded through FOCAC. In 2009, Chinese firms signed MoU with Malian government for Sugar plantation and processing (SAllA, 2015). China invested first mainly on human development and technology transfer to African officials. Between 2007-2009, about 1004 technology expects were sent to 33 Western and Eastern African countries on different Agri-business enterprises and during the process about 568 Agricultural, officials were trained. There are many Chinese agro-investment firms operating in Africa in different regions. The following tables (table 7,8 and 9) give the brief distribution of Chinese firms in East and West African countries on various farming enterprises. From (table 6, 7, 8 and 9), Eastern and Western Africa share a large number of Chinese agro-firms in 33 countries with 130 firms and more.

TABLE 7: Agricultural Investments in Africa

\begin{tabular}{llllll}
\hline Country \& year & Investor & Size(hectare) & $\begin{array}{l}\text { Type of the Market } \\
\text { enterprise(s) }\end{array}$ & Reral \\
\hline $\begin{array}{l}\text { Cameroon } \\
\mathbf{2 0 0 6}\end{array}$ & Sini Cam Iko 10000 & Rice,Vegetables,manioc local \\
\hline
\end{tabular}




\begin{tabular}{lllll}
\hline $\begin{array}{l}\text { Cameroon } \\
\text { 2007 }\end{array}$ & $\begin{array}{l}\text { Shanxi Province } \\
\text { Agribusiness }\end{array}$ & 5000 & Rice,manioc,ostriches & local \\
& Group & & \\
DRC 2009 & ZTE & 100000 & Oil palm & Internationally \\
Mali $\mathbf{1 9 9 6}$ & Sukala Refinery & 6000 & Sugar & local \\
Mali 2008 & Sukala Refinery & 10000 & Sugar & local \\
Sudan 2010 & ZTE & 10000 & Wheat and Corn & local \\
Togo 2009 & Complex Sucier & 1200 & Sugar cane & Local \\
& D'Anie & & & \\
\hline
\end{tabular}

Source: SAIIA, 2011, FOCAC,AD

Table 7, indicates a concentration of investments by Chinese companies in the Sugar industry in Mali and Togo. In Cameroon, investments by Chinese Companies were in rice, vegetables and ostriches. All these investments are done by different Chinese enterprises. These enterprises focus mostly on the local market with only palm oil targeted for an international market.

Table 8: Notable Chinese companies that invested in African Agriculture

\begin{tabular}{|c|c|c|c|c|}
\hline $\begin{array}{l}\text { Company } \\
\text { name }\end{array}$ & Host country & Activity/enterprise & Size(ha) & $\begin{array}{l}\text { Funding } \\
\text { model(source) }\end{array}$ \\
\hline CAAIC & Madagascar & Hybrid rice & & CADF \\
\hline Jiangsu SFE & Zambia & Grains,vegetables & 2300 & $\begin{array}{l}\text { Co-operation with } \\
\text { CSFAC }\end{array}$ \\
\hline Anhui SFE & Zimbabwe & Wheat,maize,Soybean,tobacco & 50000 & EXIM,Tianrui(private) \\
\hline Hubei SFE & Mozambique & Rice & 22000 & $\begin{array}{l}\text { In co-operation with } \\
\text { Wanboo and } \\
\text { Hefeng(private) }\end{array}$ \\
\hline Hubei SFE & Zimbabwe & Tobacco and vegetables & 3000 & \\
\hline $\begin{array}{l}\text { Hunan } \\
\text { Rubber } \\
\text { Group }\end{array}$ & Sierra Leone & Rubber, Rice & 135000 & EXIM \\
\hline $\begin{array}{l}\text { Jilin Overseas } \\
\text { Agricultural } \\
\text { Investment } \\
\text { and } \\
\text { Development } \\
\text { Group }\end{array}$ & Zambia & & 2000 & \\
\hline
\end{tabular}

Source: Authors compilation from SAIIA

In 2009, China had approximately 142 agricultural projects in Africa (SAllA, 2015). China also established Technology Demonstration centres in West and East Africa in an effort to transfer knowledge for smooth industrialization of agriculture in Africa. Table 8 above shows investment by Chinese Companies from countries such as Zimbabwe, Zambia, Sierra Leone, Mozambique and 
Madagascar, with these investments in Wheat, Maize, Tobacco, Vegetables, Rubber, rice and hybrid rice. The funding models are from different entities from different provinces.

Table 9: Notable Chinese companies that invested in African Agriculture....conti..

\begin{tabular}{|c|c|c|c|c|}
\hline $\begin{array}{l}\text { SDIETC } \\
\text { Group(Shandong) }\end{array}$ & Sudan & Cotton & 6700 & \\
\hline Tianli Group(Shanxi) & Madagascar & Cotton & 60000 & CDB/CADF \\
\hline ZTE Energy & $\begin{array}{l}\text { Democratic } \\
\text { Republic of } \\
\text { Congo }\end{array}$ & $\begin{array}{l}\text { Palm oil, maize, } \\
\text { cassava (biofuel) }\end{array}$ & 5300 & \\
\hline COVEC & Nigeria & Rice & 2000 & \\
\hline $\begin{array}{l}\text { China-Africa Cotton } \\
\text { Company(Shandong) }\end{array}$ & $\begin{array}{l}\text { SADC except } \\
\text { Lesotho and } \\
\text { South Africa }\end{array}$ & Cotton & & CADF \\
\hline Lianfang(Shandong) & Zambia & Cotton & $>10000$ & \\
\hline Junde(Shandong) & Zimbabwe & Cotton & & \\
\hline Jinfang & Zimbabwe & Cotton & & \\
\hline Wudi(Hubei) & Zambia & $\begin{array}{l}\text { Cassava,soybean, } \\
\text { maize(biofuel) }\end{array}$ & 80000 & \\
\hline Wanboo(Hubei) & Mozambique & Rice & 20000 & $\begin{array}{l}\text { CDB/CADF in } \\
\text { cooperation } \\
\text { with Hubei SFE }\end{array}$ \\
\hline Hefeng(Hubei) & Mozambique & Sugarcane & 2000 & $\begin{array}{l}\text { In co- } \\
\text { operation with } \\
\text { Hubei SFE }\end{array}$ \\
\hline Hoode(Henan) & Mozambique & & 1000 & \\
\hline Tianrui(Anhui) & Zimbabwe & Maize, tobacco & 3000 & $\begin{array}{l}\text { In co- } \\
\text { operation with } \\
\text { Anhui SFE }\end{array}$ \\
\hline Tianyuan(Shandong) & Sudan & Cotton & 1300 & \\
\hline Fenghui(Shandong) & Sudan & Cotton & 3000 & \\
\hline Yingma(Hunan) & Madagascar & Hybrid rice & 7000 & \\
\hline Yuemei(Zhejiang) & $\begin{array}{l}\text { Nigeria, } \\
\text { Tanzania, } \\
\text { Togo, Sierra } \\
\text { Leone, Mali. }\end{array}$ & Cotton & & \\
\hline
\end{tabular}

Note: CADF is China-Africa Development Fund from China Development Bank (CDB)

Source: Authors compilation from: SAIIA, 2011.SAIIA, 2015

From the above tables, it is clear that there is a lot of Chinese presence in African agriculture. There is a lot of concentration into the cotton industry, which can be mostly attributed to Chinese Cotton demand to boost their massive industrial sector.

\section{South Africa-China Relations}


South Africa maintains a robust diplomatic relations with a number of global players. The transition period from apartheid government saw the new government readjusting its foreign relations. South Africa joined South African Development Community (SADC), African Union (AU) and the Movement of Non-Aligned Nations (MNAN) which are all the bodies inside the African continent. The country is also a member of international bodies outside the continent such as commonwealth and United Nations (UN) general assembly; also is a member of G20 countries.

Recently, the South African government is focusing more on South-South ties, particularly in light of South Africa's relationship with China (OBG, 2016). The relationship took a very positive turn in 2011 when South Africa joined Brazil, Russia, India and China (BRIC) bloc of emerging economies, which subsequently became BRICS when South Africa is included. Currently, among the BRICS bloc, China is a leading trade partner with South Africa (Department of Trade and Industry-South Africa, 2017). While the specific purpose and tangible results of the BRICS grouping is debatable and appears to vary across participating nations (Grimm,2013), these interactions provide for high-level meetings which often include a significant participation by large business delegations. Consequently, if nothing more, these meetings are an opportunity for business networking and for state-facilitated deals between participating nations; China is certainly by far the most relevant partner.

The official relations between the Peoples Republic of China (PRC) and Republic of South Africa (RSA) are dated back as far as from the 1997/1998. The collapse of the then Apartheid regime in South Africa and the fall of the Soviet Union in the early 1990s in China opened up some possibilities of official relations between the two countries. China and South Africa started forming cultural centres in Beijing and Pretoria which were known as; South African Centre for Chinese Studies and Chinese Centre for South African studies which were a step towards diplomatic relations (DAFF, 2014).

\section{The Belt and Road Initiative}

Belt and Road Initiative (BRI), is a policy direction that is spearheaded by Chinese President, Xi Jinping. The initiative started in 2013 and was in 2015 documented and published by National Development and Reform Commission and ministries of Foreign affairs and commerce (The State council, 2015). According to the state security council of the people's republic of China (2015), "The initiative aims to promote orderly and free flow of economic factors, highly efficient allocation of resources and deep integration of markets by enhancing connectivity of Asian, European and African continents and their adjacent seas" In 2017 may 14-15 during the Belt and Road Forum for International Cooperation held in Beijing, saw many countries supporting the initiative and hailing it for its future potential for the benefits of their countries(Yu,2017).

There are 29 heads of states and representative who attended the 2017 meeting from 130 countries (Yu, 2017). Policy researchers are in support of the programme as their say it will shape the skewed economic global balance of forces and brings many benefits to countries within the belt as most of the countries within the Belt and Road are developing (Yu, 2017).

\section{Table 10: Notable Belt and Road studies}

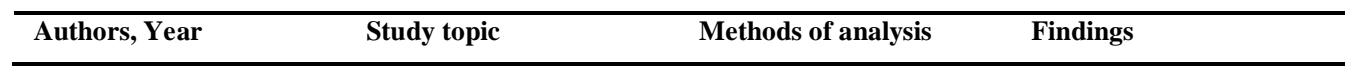


International Journal of Academic Research in Business and Social Sciences Vol. 9, No. 2, Feb, 2019, E-ISSN: 2222-6990 @ 2019 HRMARS

\begin{tabular}{|c|c|c|c|}
\hline $\begin{array}{l}\text { Christopher K } \\
\text { Johnson,2016 }\end{array}$ & $\begin{array}{l}\text { President Xi Jinping's } \\
\text { "Belt and Road" } \\
\text { Initiative, A practica } \\
\text { assessment of the Chinese } \\
\text { Communist Party } \\
\text { Roadmap for China;s } \\
\text { Global Resurgance }\end{array}$ & Descriptive analysis & $\begin{array}{l}\text { Chinese are peacefully } \\
\text { advancing global } \\
\text { development }\end{array}$ \\
\hline $\begin{array}{l}\text { Min He,Zequn } \\
\text { Huang,Ningning } \\
\text { Zhang,2016 }\end{array}$ & $\begin{array}{l}\text { An Empirical Research on } \\
\text { Agricultural Trade } \\
\text { between China and "The } \\
\text { Belt and Road" Countries: } \\
\text { Competitiveness and } \\
\text { Complementarity }\end{array}$ & $\begin{array}{l}\text { Revealed Comparative } \\
\text { Advantage(RCA) and }\end{array}$ & $\begin{array}{l}\text { 1.Agricultural product } \\
\text { trade between China and } \\
\text { the Belt and Road } \\
\text { countries has developed } \\
\text { rapidly, and has a } \\
\text { tendency to keep } \\
\text { increasing } \\
2 . \text { The agricultural } \\
\text { product trade between } \\
\text { China and the Belt and } \\
\text { Road countries is highly } \\
\text { concentrated, mostly in } \\
\text { Indonesia, Malaysia, } \\
\text { Thailand and Vietnam in } \\
\text { Southeast Asia. }\end{array}$ \\
\hline $\begin{array}{l}\text { Helen Chin, Winnie } \\
\text { He,2016 }\end{array}$ & $\begin{array}{l}\text { The Belt and Road } \\
\text { Initiative: } 65 \text { countries and } \\
\text { Beyond }\end{array}$ & Descriptive & $\begin{array}{l}\text { There are } 65 \text { countries } \\
\text { within the silk including } \\
\text { China and more other } \\
\text { countries have shown } \\
\text { interest to the initiative } \\
\text { including sub-Sahara } \\
\text { African countries. }\end{array}$ \\
\hline $\begin{array}{l}\text { Orestes Georgiou } \\
\text { Daniel\& Mick Ryan,2018 }\end{array}$ & $\begin{array}{l}\text { The Belt and Road } \\
\text { Initiative: Opportunities } \\
\text { and Challenges for } \\
\text { EUSMEs }\end{array}$ & Descriptive approach & $\begin{array}{l}\text { BRI, presents an } \\
\text { opportunity for EU SMES } \\
\text { many areas such e- } \\
\text { commerce, agriculture, } \\
\text { finance among others }\end{array}$ \\
\hline
\end{tabular}

Source: compiled by Author from the studies above

The belt and Road initiative is a continuing Chinese project that continues to be adopted by many countries for a shared future and peace (Helen and Winnie, 2016). According to Helen and Winnie (2016), more than 65 countries are within the Silk Road and South Africa falls within countries that participated or even shown interest in working with China. Accordingly, the recorded participatory signature by South Africa is seen in AllB signatory (Helen and Winnie, 2016). South Africa in 2018, hosted the first conference on the Belt and Road (Thokozani and Lavhelesani,2018). The conference was held in Durban University of Technology engaging on advantages that come with the initiative for the African continent(Thokozani and Lavhelesan,2018).As a result, many studies are being carried 
to assess its impact and its potential impact (see table 3). According to Thokozani and Lavhelesani(2018), the impact of the initiative are already being felt already in Asia where are already implemented, a number of bridges have been belt and trade within the Belt and Road countries is incrementing year in year out.

Experts suggest that Belt and Road is inevitable the fastest growing policy that is easily adopted and is poised to spread across the globe (Wenxian et al, 2018). Accordingly, it is strongly argued that China want to strengthen its Free Trade Agreements(FTA) into the world particularly to countries that fall with the Belt and Road routes(Wenxian et al,2018). However, even though Africa was not in the initial 65 countries, recent address by President Xi Jing ping and Premier Li Keqiang has vividly elaborated on the unrestrictive posture of the Belt and Road. Subsequently, It is on those bases that this paper looked at possible areas that could be presented by South African economy which at the same time fits within the frameworks of the Belt and Road. Additionally, the paper will look at areas that will be beneficial to both the PRC and RSA economies and the peoples of these countries.

\section{Results and Discussions}

There are no comprehensive agricultural projects between South Africa and China as compared to other African countries. Trade relations between the two countries have been increasing for the last decade. Accordingly, South Africa for years has been experiencing a positive trade balance in agriculture. In 2018, the country saw a sustained increment of agricultural exports to the value of R20.89 billion resulting to a net trade of R3, 736 billion.

The results indicate that China's demand for South African agricultural commodities will increase in the short to medium term, due to factors such as the demand for animal feed and a growing middle class and living standards of Chinese people. Furthermore, the big manufacturing industry continues to fuel an increased demand for cotton and wool. It is anticipated that the increased demand for high value products in China will continue to increase because of the stimulated consumer taste and increased purchasing power. This is evident from a rapidly increasing import of processed products such as wine, cheese, coffee and tea. 


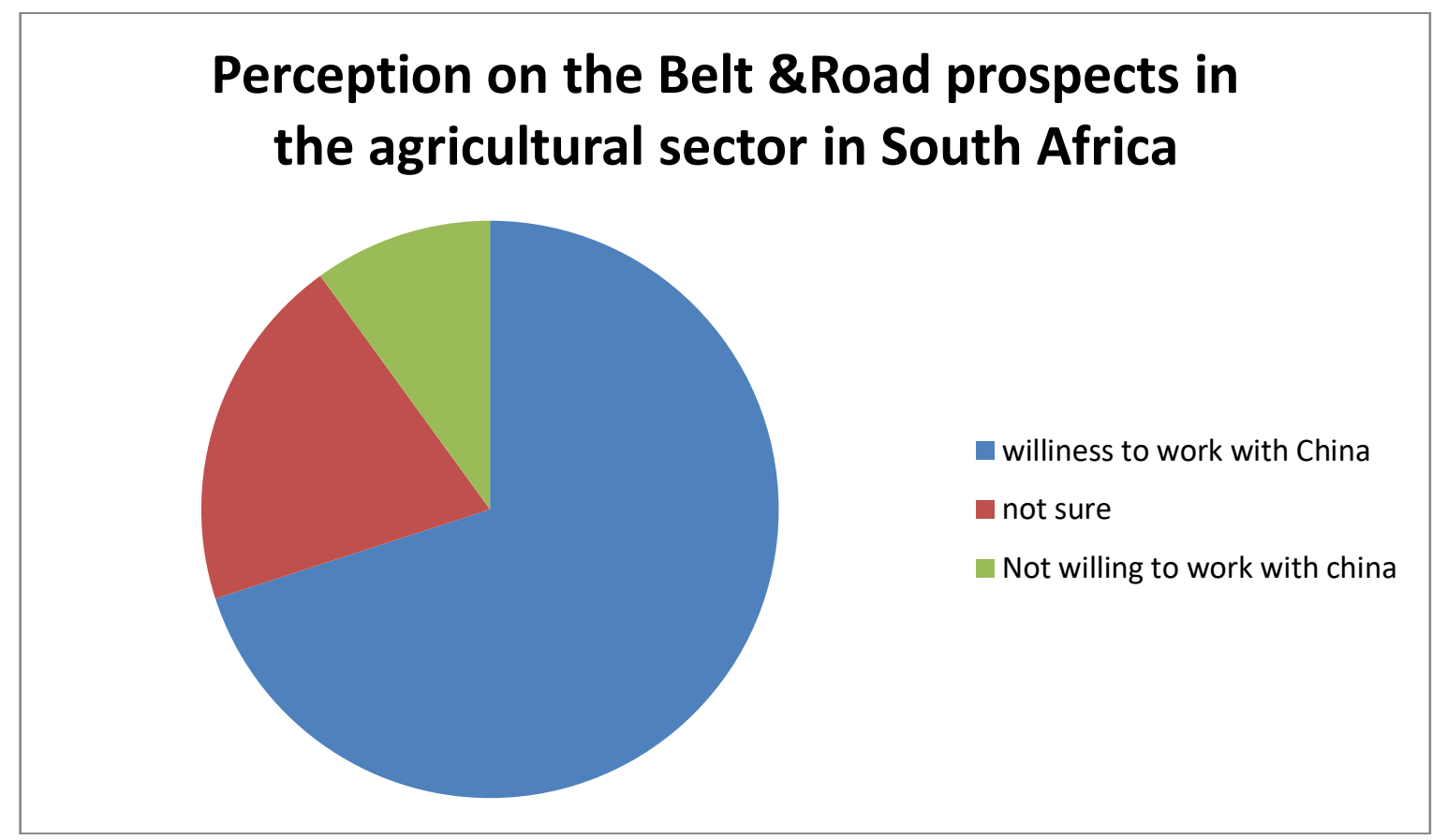

Source: compiled by the author from the survey results

Figure 4: Perception on Belt and Road prospects in Agricultural sector in South Africa

On the prospects of Belt and Road towards agricultural cooperation between China and South Africa, the results from the survey (see figure 4) indicate that 80 percent of South African experts are willing to work with China on agricultural cooperation. In addition, 15 percent indicated that they are not sure towards about future cooperation and $5 \%$ were not willing at all to work with China. There are many reasons behind those who are for cooperation. Among them is the strong South African government commitment to work with many international players and many existing agreements with China. According to the experts, agricultural cooperation will fit correctly currently, since South African government is targeting a large volume of investments into agricultural sector. Accordingly, this implies that the prospects of Belt and Road in agricultural sector in South Africa are high consideration the call by South African President for more investments into the agricultural sector. Lastly, the areas where South African government is focusing in agriculture are presented in figure 4 according to the level of priorities from these agricultural expects. 


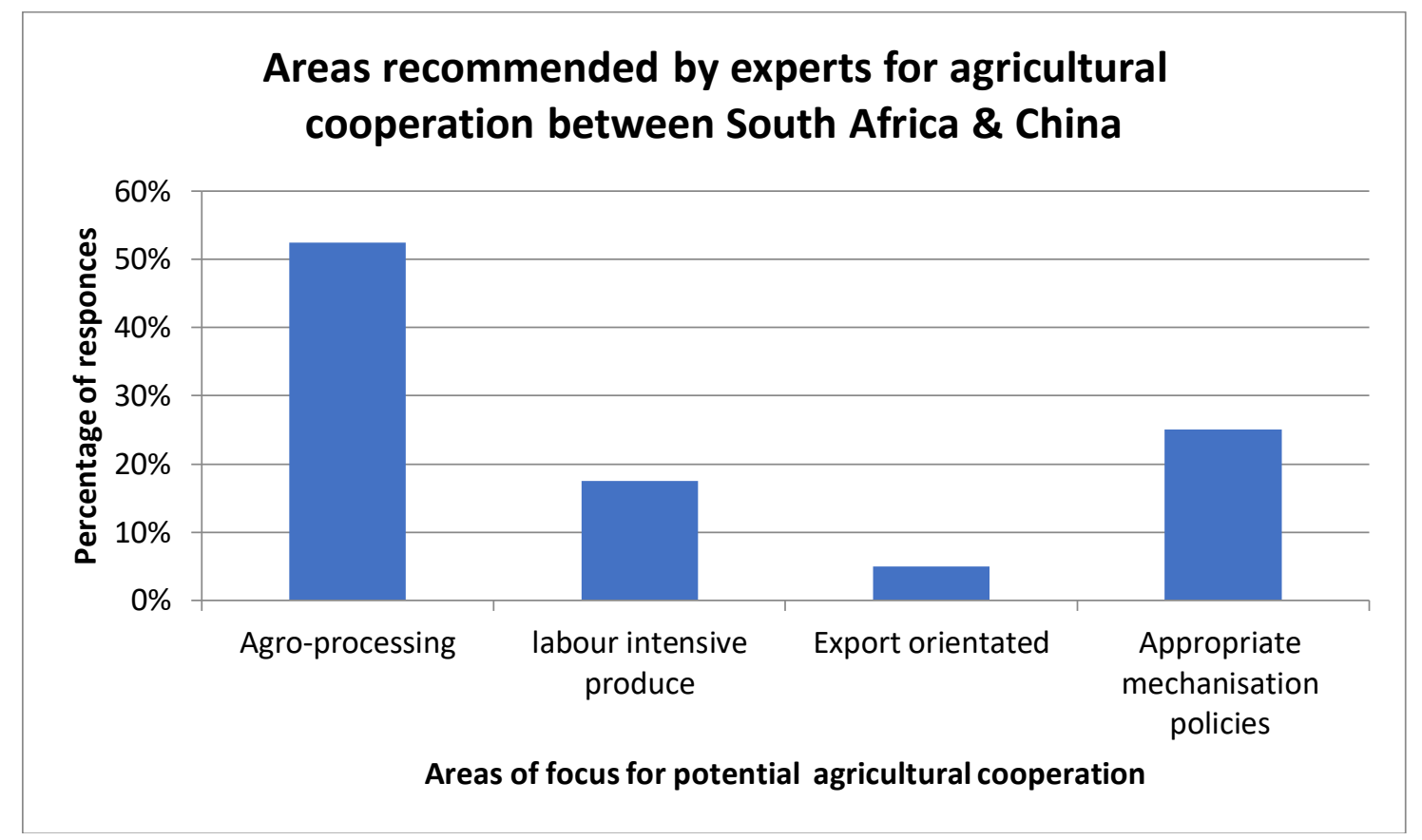

Source: Author from the Survey conducted.

Figure 5: Areas recommended by experts for agricultural cooperation between South Africa and China.

University professors were very sceptical though, because there are many studies that do not see Chinese investment resulting into economic growth on the respective investment destinations in Africa (Gumede, 2014). However, Studies such those by Johansein Rutaihwa, on China-Tanzania where a significant employment was created from these projects, gives a convincing confidence to future cooperation with China, according to the experts. Emphases on projects that are built on real mutual benefits were encouraged. These results suggest that, South Africa is willing to work with China and the next process should be measures that are put forward by both countries to encourage businesses and organisations in their respective countries to implement at an operational level.

\section{Conclusion and Recommendation}

In light with the understanding of the already mentioned high demand from the Chinese consumers, particularly the growing middle class for high quality products that is healthy and organic. ChinaSouth African agribusinesses should use these opportunities presented by these multilateral platforms to increase food security of these countries and contribute to the global agendas of feeding the world exponential growing population.

South African government is putting more attention on policies and rules that will allow investing in the country more beneficial to the investors as well as the country. In that regard, the call by South African government for more investment under the leadership of President Cyril Ramaphosa, 
possesses a strong indication for more investment cooperation particularly to sectors such as agriculture that are part of his priorities in his term of office.

South African investment environment is good for any international investor that wants to penetrate not only South Africa but also the entire continent that has a growing middle class and working class with growing incomes, which possesses a strong consumer demand in the medium to long term. South Africa has a strong logistics infrastructure that is recognised in the world, with world-class ports and sophisticated banking systems. Many multinationals have used South Africa as a gateway to the entire continent with their bases in South Africa. With the South African aim to expand its manufacturing, the Belt and Road investments should not miss the opportunity presented by South African environment.

In addition, government decision on prioritizing the grains and horticultural subsectors shows high level of decisions that are informed by research and understanding of areas of focus for medium to long-term gains. For example, there is no doubt the horticultural subsector in agriculture together with field crops are amongst the largest employing sectors in South Africa. This stimulus package focused on the horticultural subsector because it also enjoys an increasing international Asian market demand led by China. The Belt and Road coincides with the South African government programme called Operation Phakisa that seeks to create an significant number of Jobs in the agricultural value chain. Through the Department of Trade and industry in South Africa, Belt and Road will have to focus on agro-processing to balance the trade imbalances between China-South Africa. In addition, the improvements of Special Economic Zones(SEZ) in South Africa with better economic incentives for investors brings more prospects for the Belt and Road prospects in South Africa in the short to Medium term.

\section{Theoretical Contribution of the Paper}

The studies of "International Political Economy" (IPE) are mostly defined as the study of "linkages between economic and political activities at the level of international affairs" (Harlen,1999).IPE as a field is because of combination of political studies and economic studies. These fields were studied separately academically before untilled it was recognized that they co-exist with one another. It has long been recognized that economic factors shape political decisions, just as political factors may have a decisive influence on economic choices" (Harlen, 1999). In that regard, this paper assesses the position of the political economy between South Africa and China with regards to whether political agreements taken at inter country forums such as BRICS, FOCUS does come to fruiting in terms of implementation. Accordingly, the international relations theories that this paper aligned itself on are: dependency theory, realism (Helleiner, 2002.) and "Neo-liberal Institutionalism" theory(Lehlogonolo,2016). He argues that, "Neo-liberal institutionalism argues that states are rational international actors and thus it is in their rational state behavior to enter into cooperation with other states, to maximize their mutual interests and absolute gains, in a harsh and unpredictable international system. China and South Africa benefit from mutual interests and maximum absolute gains in their cooperative partnership, through rapid and extensive bilateral trade relations" 
It would be therefore within Chinas interests to look at its operation to maintain long lasting international relations with the entire African continent and particularly South Africa with strong democratic institutions to limit any bias in relation to any unfair economic activities.

\section{References}

Andrew, J. (2016, July). Agriculture Overview. Oxford Business Group (OBG) ,pp139-147.

Alden, C. 2006 (b). "China- Africa relations: the end of the beginning" in Draper,P. and ie Pere, G(eds).(2005).Enter the Dragon: Towards the Tree Trade Agreement Between China and the Southern Africa Customs Union. Johannesburg, Gauteng: Institute for Global Dialogue and the South Africa Institute for international Affairs.p137

Alden, C. (2007).China in Africa.London:Zed Books.

Amendolagine, V., Boly, A., Coniglio, N. D., Prota, F., \& Seric, A. (2013). FDI and local linkages in developing countries: Evidence from sub-Saharan Africa. World Development, 50, 41 -56.

Bernard, H.R. (1995). Research Methods in Anthropology, Second Edition. London: Sage Publications.

Bless, C., Smith, C.H., Sithole, S.L. (2013). Fundamentals of Social Research Methods. An African Perspective.

Brautigam, D., \& Xiaoyang, T. (2009). China's engagement in African agriculture: 'Down to the countryside'. The China Quarterly, 199, 686-706.

Carmody, P. (2013). The new scramble for Africa. Cambridge, UK: Pololicy. Cheng, Y. W., Qian, X. W. (2010).China's Outward Direct Investment in Africa.working paper.,pp1-6.

Chili, O.(2014 November 07). Realising West Africa's true agricultural potential: African Development Bank. Available Online: https://www.afdb.org/en/blogs/measuring-the-pulse-of-economictransformation-in-west-africa/post/realising-west-africas-true-agricultural-potential-13740/.

Chinese Agricultural Investment with Africa (2018).htthttp://www.sais-cari.org/data-chineseagriculturalinvestmentsinafricap://www.chinadaily.com.cn/a/201801/26/WS5a6a5053a3106e7dcc 136a9f.html.

Davies, M. (2005). "The rise of China and commercial consequences for Africa" in Draper,P. and ie Pere, G(eds).(2005).Enter the Dragon: Towards the Tree Trade Agreement Between China and the Southern Africa Customs Union. Johannesburg, Gauteng: Institute for Global Dialogue and the South Africa Institute for international Affairs.p154

Department of Agriculture. (2008). National research and development strategy.Available online:http://www.gov.za/sites/www.gov.za/files/Research and Development Strategy1 0.pdf.

Department of Trade and Industry. South Africa (2017). Industrial Development:http://www.thedti.gov.za/industrial_development/sez.jsp.

Denzin, N.K., Lincoln, Y.S. (eds.) (2000). Handbook of Qualitative Research. London: Sage Publications. Department of Trade and Industry (DTI). (2017).Industrial Policy Action Plan (IPAP) 2017/2018-2019/2020. Forum on China- Africa Cooperation. (2006 August 02). "The Chinese Government Grant \$500,000 to support NEPAD Nurses and Midwives Post-Graduate Training Program".

Frank, T. M. (2001 February). Are Human Rights Universal?" in Foreign Affairs, 80(1),191-204

Forum for China-Africa Cooperation (2015):2001-2015: Ministerial Conferences

Available online: http://www.focac.org/eng/, Accessed [27 January 2018]. 
Fred, H. (2003). Obstacles to Agricultural Development in the Eastern Cape: report for the Eastern Cape provincial growth and development plan. [Accessed October 2015].

Gu, J., \& Carty, A. (2014). China and African development: Partnership not mentoring. IDS Bulletin, 45(4), 57-69

Gu, J., Chen, Y., \& Zhang, Y. (2014). Understanding China's approaches to international development. IDS policy briefing, 75. Brighton: IDS.

Gumede, W. (2014 December 10). The Bricks Alliance:Challenges and opportunities for South Africa and Africa. available online: http://triplecrisis.com/the-brics-alliance-challenges-and-opportunities-forsouth-africa-and-africa/.

Grazia, D. S. (2018). The Impact of FDI in land in agriculture in developing counties on host country food security. Journal of World Business,53,75-84.

Grimm, S., Kim, Y and Ross, A. (2014). South Africa relations with China and Taiwan: Economic realism and the 'one-China' doctrine. Accessed October 23, 2015.Available online: http://www.ccs.org.za/wpcontent/uploads/2014/02/Research-Report_FEB2014_Formatting.pdf

Hazell, P.B.R., and Ramasamy, C. (1991). The Green Revolution Reconsidered The Impact of High-Yielding

Rice Varieties in South India. Baltimore, London: Johns Hopkins University Press.

Harlen, C.M. (1999). "A Reappraisal of Classic Economic Nationalism and Economic Liberalism" in international studies quarterly 43,733-733

Helen, C., Winnie, H. (2016). The Belt and Road Initiative: 65 countries and Beyond. Fung Business Intelligence Centre.

Helen, L. S. (2011). Understanding China's Agricultural Investments in Africa. South African Institute of International Affairs, African perspective, Global Insights. Available online: https://www.saiia.org.za/occasional-papers/45-understanding-china-s-agricultural-investments-inafrica/file.

Helleiner, E. (2002). Economic Nationalism as a challenge to Economic Liberalism? Lesson from the 19th Century in International studies quarterly, 46,307-329.

Hidden, S., and Cilliers, J. (2014 September 15). Institute for Security Studies: emerging water crises inSouthAfrica.Availableonline:https://www.issafrica.org/uploads/AF11_15Sep2014.pdf.

International Trade Centre (ITC).(2017). Available online:www.trademap.org/ www.macmap.org.

Ilana, B. (2006), China in Africa: Friend of Foel?, China`s contemporary political and economic relations with Africa.

Johansein, L.R., Amina, R.M.(2011).Empirical Analysis of China-Africa Economic and Trade Cooperation for Good or Bad: A Case of Tanzania.hrmars.1(3),1-3.

Kapuya, T. (2016 April 07).Trade Intelligence Report, Profiling South Africa-China 'agricultural Trade Relationship.AgriculturalBusinessChamber.Availableonline:https://agbiz.co.za/uploads/AgbizNews1 6/160407_TradeChina.pdf.

Lehlohonolo, M. (2016, March).China-South Africa Comprehensive Strategic Partnerships.ReserchGate.Availableonline:https://www.researchgate.net/publication/301732224_C hina-South_Africa_A_Comprehensive_Strategic_Partnership?.

Li, X., \& Carey, R. (2014). The BRICS and the international development system: Challenge and convergence? IDS evidence report; 58.Brighton: IDS. 
Li, X., Qi, G., Tang, L., Zhao, L., Jin, L., Guo, Z., et al. (2012). Agricultural development in China and Africa: A comparative analysis. London: Routledge.

Lu, J. (2015 October). Chinese Agricultural investments in Africa: Motives, Actors and Modalities, South African Institute of Internal Affairs (SAllA), African Perspectives; Global insights.

Lu, J. (2015).China's agricultural investments in Africa: Motives, actors and modalities. Available online: https://www.saiia.org.za/occasional-papers/913-chinese-agricultural-investment-in-africa-motivesactors-and-modalities/file.

Lu, J., Li, X., \& Fu, G. (2015). The challenges of China's food and feed economy. Future Agricultures Working Paper, 131. Brighton and Nairobi: Future Agricultures Consortium.

Lumumba-Kasongo, T. (2011). China-Africa relations: A neo-imperialism or a neo-colonialism? A reflection. African and Asian Studies, 10(2-3), 234-266.

Marshall, P.A. (2003). Human subjects protections, institutional review boards, and cultural anthropological research. Anthropol Q;76(2):269-85.

MOFCOM. (2012). Manual for the management of foreign aid training (商务部对 外援助培训项目实施 管理工作手册 (2010年8月修订版)) published August 2012.

Msimang, D. (2018 January). Friends Through Time. Deep Bonds of friendship, Mutual Trust and Benefits mark two Decades of South Africa-China ties. China-Africa magazine.10,p18.

Mike, B. (2011 February).Eastern Cape Socio-Economic Consultative Council (ECSECC). How to develop Agriculture in Eastern Cape: Famers weekly.p13

National Agricultural Marketing Council(2013): Markets and Economic research Center. 2013 SA Friut Trade Flow. Availableonline :http://www.namc.co.za/upload/Fruit-flow-trade-No.11-SeptEdition.pdf.

National Department of Agriculture, Forestry and Fisheries. (2018).Directorate: Statistics and Economic Services.

NEPAD. (2013).Transforming Africa. Agriculture in Africa. Transformation and outlook .Available online: http://www.un.org/en/africa/osaa/pdf/pubs/2013africanagricultures.pdf.

Nkwi, P., Nyamongo, I., Ryan, G. (2001). Field Research into Social Issues: Methodological Guidelines. Washington, DC: UNESCO.

OECD, AfDB, UNDP and ECA. (2013). African Economic Outlook 2013. Paris: Organisation for Economic Cooperation and Development.

Pelto, P. and Pelto, G. (1997). Studying Knowledge, Culture and Behavior in Applied Medical Anthropology. Med Anthropol Q.11(2),147-63.

Pope, C. and Mays, N. (2000).Qualitative Research in Health Care. London: BMJ Books.

Robert, G. (1997). The Political Economy of International Relations. Princeton: Princeton. University Press, 86.

Renkow, M. (2000). Poverty, Productivity, and Production Environment: A review of the Evidence:Food Policy. 25(2) 463-478.

Schensul, J., LeCompte, M.,Ethnographer's T. (1999). Walnut Creek, CA: Altamira Press.

Scoones, I., Cabral, L., \& Tugendhat, H. (2013a). New development encounters: China and Brazil in African agriculture. IDS Bulletin, 44 (4), 1-19. 
Sven, D.,Yejoo ,K.,Ross ,A., and Xin, X.(2014). South African Relations with China and Taiwan Economic realism and the "One-China" doctrine. Centre for Chines Studies and Open Society Foundation for South Africa.

Sanjari, M., Bahramnezhad, F., Cheraghi, M. A. (2014). Ethical challenges of researchers in qualitative studies: the necessity to develop a specific guideline. Journal of medical ethuics.Tehran University of Medical Science.

Sandry, R., Edinger, H. (2009). Examining the South Africa-China agricultural trading relationship. Nordiska Afrikainstitutet ,42.p10-15

Saunders, M., Lewis, P., Thornhill, A. (2012). Research Methods For Business Students. $6^{\text {th }}$ Ed.

Subramanian, A. (2013). 'The Mauritian Success Story and Its Lessons' in A. K. Fosu, (ed.), Achieving Development Success: Strategies and Lessons from the Developing World. Oxford: Oxford University Press, pp204-231.

Taylor, I., \& Xiao, Y. (2009). A case of mistaken identity: “China Inc." and its "Imperialism" in sub-Saharan Africa. Asian Politics and Policy, 1(4), 709-725.

Taylor, I., Kopinski, D., \& Polus, A. (Eds.) (2014). China's rise in Africa: Perspectives on a developing connection. London: Routledge

Taylor, I. (1997). China's foreign policy towards Southern Africa in the socialist modernization period. Johannesburg: East Asia Project, Department of International relations, University of the Witwatersrand.

Taylor, I. (2004a). The all-weather friend? Sino-Africa interaction in the twenty-first century.

Taylor, I. \& Williams, P.(eds) (2004).Africa in International policy External involvement on the continent. London, Routledge.

The State Council the people's republic of China, (2015).Action plan on the Belt and Road Innitiative.Availableonline:http://english.gov.cn/archive/publications/2015/03/30/content_281475 080249035.htm.

Thokozani,S. and Lavhelesani,M.(2018). Belt and Road Initiative, Alternative Development Path for Africa. Pretoria, Gauteng. African Institute of South Africa.

Tracey, S. and Michael, A. (2000 September).The Crisis of Agricultural Unemployment: Available online: Trade and Industrial Policy Secretariat (TIPS).Available online:http://www.tips.org.za/files/415.pdf, Assessed[20 September 2017].

Tugendhat, H., \& Alemu, D. (2016). Chinese agricultural training courses for African officials: Between power and partnerships. World Development, 81, 71-81.

UNCTAD. (2010). Economic Development in Africa: South-South Cooperation: Africa and the New Partnership for Development. New York and Geneva: United Nations.

UNCTAD. (2013). World Investment Report 2013. New York and Geneva: United Nations.

UNCTAD. and UNDP. (2007). 'Asian Foreign Direct Investment in Africa: Towards a New Era of Cooperation Among Developing Countries', UNCTAD Current Studies on FDI and Development No. 3. New York and Geneva: United Nations University Press.

Van, D. W, K. (2004). "Enter the dragon: China's strategic importance and potential for African business" in Convergence,5(4), 72-75

Weng, L., Boedhihartono, A. K., Dirks, P. H., Dixon, J., Lubis, M. I., \& Sayer, J. A. (2013). Mineral industries, growth corridors and agricultural development in Africa. Global Food Security, 2(3), pp195-220. 
Wenxian, Z., Ilan, A., Christoph, L. (2018). China's Belt and Road Initiative, Changing the Rules of Globalisation. Gewerbestrasse. Switzerland. Springer International Publishing AG part of Springer Nature.

White, L. (2013). Emerging powers in Africa: Is Brazil any different? South African Journal of International Affairs, 20(1), 117-136

Xi, J. (2014). The Governance of China. Beijing, BJ: Foreign Language Press.

Xin,L. (2017 March 03). "Belt and Road a big lure for execs".Available online: www.usa.chinadaily.com.cn/business/201703/03/content_28416976.htm

Xu, X., Li, X., Qi, G., Tang, L., \& Mukwereza, L. (2016). Science, technology, and the politics of knowledge: The case of China's agricultural technology demonstration centers in Africa. World Development, 81, pp82-91.

Yu, L. (2017 May): Globalisation 2.1 envisaged. The Beijing Review.60,12-17.

Zhang, C., Li, X., Qi, G., \& Wang, Y. (2015). Interpreting China-Africa agricultural encounters: rhetoric and reality in a large-scale rice project in Mozambique. Future Agricultures Working Paper, 126. Brighton and Nairobi: Future Agricultures Consortium.

Zhang, Y., Li, H., Li, Y., \& Zhou, L. A. (2010). FDI spillovers in an emerging market: The role of foreign firms' country origin diversity and domestic firms' absorptive capacity. Strategic Management Journal, 31, 969-989. 